\title{
The platform economy can deliver for its workers too
}

Written by: OECD

Last update: 23 January 2020

Have you ever used your smartphone to hail a taxi? Order in lunch? Or to find the help you need, whether from a cleaner or a childminder? If you have, then like millions of people, you probably did so via digital platforms. Every day people are connecting online, whether to use or provide myriad services.

These digital platforms have made life easier for consumers everywhere, by improving the quality, cost and accessibility of services. But as well as being digital, these platforms also depend on labour. They have opened up new work opportunities for millions of people. Some people use them as a main job, others to earn additional income. Others like the flexibility that they offer to fit work around other responsibilities and find a better work-life balance for themselves.

However, while online platforms have created new lines of work and lowered barriers to employment, the quality of some of these new forms of work has drawn the attention of policymakers. Indeed, a closer look shows that behind these positive aspects lurks a somewhat darker reality, with poor and precarious working conditions for some workers. This could mean putting in long hours to make work pay, or remaining constantly on call, with unpredictable income and work schedules.

And, as technology has reshaped how people find and do their work, social and labour market protection have had not always kept up. In many countries, social benefits, employment regulations and collective bargaining have long been based on the idea that people have a stable, full-time job as a full-time employee working on an open-ended contract for a single employer. But nowadays, many gig workers are not formally employees of the firm, but are considered selfemployed. Rather than go to work and get paid a wage, they "sell" their services to the platform company. This status also means they may not be covered by the standard rights and protections which employees have. Protections against unfair dismissal, support of minimum pay, or access to unemployment benefits and pensions, simply do not apply to many platform workers. Nor do they have the right to organise and bargain collectively.

Some platform workers might not need these protections: they are successful, have many clients and have a strong ability to set their rates of pay as well as their 
working conditions. Others, however, might may be less well set up. They might, for example, be dependent on one single client or platform, which makes them vulnerable - particularly if they have few alternative job options, which reduces their bargaining power.

Whether all platform workers really are self-employed or employed by the platforms they work for has become a heated legal question in several countries. In some cases, workers might even be falsely self-employed. Their employer (or the platform) might have chosen self-employment over a standard employeremployee working arrangement in order to avoid taxes and regulations. In most OECD countries, existing labour law provides the means to deal with cases like this, so that such workers can be re-classified and therefore have access to the rights and protections to which they are entitled as employees. In practice, correcting misclassification may need additional action, such as reducing any tax incentives, or making it easier for workers to challenge their status legally. Also, policymakers could toughen penalties for mis-classification and strengthen the labour inspectorate's capacity to detect breaches.

Some workers, however, will remain genuinely difficult to classify. In fact, while there have been a few headline-grabbing legal breakthroughs, court cases around the employment status of platform workers have generally resulted in mixed outcomes, which proves the difficulty of classification. While some of these workers have features in common with self-employed workers, they also share some characteristics and therefore vulnerabilities of employees. This calls for new thinking about ways of extending rights and protections to these workers.

Take the right to organise and bargain collectively. Self-employed workers do not usually have the right to do so, because they are considered as businesses. Bargaining about rates could be treated as collusion by competition authorities since it could be detrimental to consumers. But, in reality, many platform workers operate alone and are unable to collude on prices. And even if formally classified as self-employed, they rarely can set the price of their services and have no more market power than regular employees. This suggests that extending collective bargaining rights to them may be necessary.

Several OECD countries have already sought to grant collective bargaining rights for some self-employed workers in unbalanced power relationships, such as those who are financially dependent on one client, either through tailored interventions in the labour law, such as Canada, Germany, Spain and Sweden or exemptions to the law prohibiting cartels for specific forms of self-employment or sectors. For example, in Ireland, there are explicit exemptions from competition law for three professions: voice-over actors, session musicians and freelance journalists. In Australia, the Competition and Consumer Act 2010 allows businesses to collectively negotiate with suppliers or customers, where such 
action is assessed as being in the public benefit. Some platform workers might be able to benefit from these exemptions.

Social partners are also adjusting to these new challenges. Some unions have been courting new members by focusing on classification issues, lobbying for public policy interventions or setting up specific branches to address gig workers' concerns. New non-traditional labour organisations are emerging and are leveraging new technology to engage with workers. A good example is the Coworker.org initiative, an online platform that helps people create companyspecific networks to collect data and shape their concerns and demands into coherent campaigns.

Both traditional collective bargaining and new forms of social dialogue between those who create and establish digital platforms and those who work behind the scenes to serve clients, have a role to play in addressing the challenges posed by a changing world of work. Policymakers should encourage unions and employers' organisations to expand their membership to new forms of business and the "non-standard" forms of work they generate, without discouraging the emergence of other forms of organisation or new, innovative lines of business. It is only by including workers' voices in the platform world that we can build a future of work for everyone - and that includes the driver you hailed.

@OECD Observer Q1-Q2 June 2019

\section{References}

OECD (2019), OECD Employment Outlook 2019: The Future of Work, OECD Publishing, Paris, https://doi.org/10.1787/9ee00155-en http://dx.doi.org/

OECD (2018), The Future of Social Protection: What Works for Non-standard Workers?, OECD Publishing, Paris, https://doi.org/10.1787/9789264306943-en. http://dx.doi.org/ 